\title{
Preferred attributes of entrepreneurial opportunities: A conjoint and cluster analysis study
}

\author{
B. Urban* and A. Stacey \\ Graduate School of Business Administration, Wits Business School, University of Witwatersrand, P.O. Box 98, Wits 2192, South Africa \\ *To whom all correspondence should be addressed \\ Boris.Urban@wits.ac.za
}

\begin{abstract}
This paper builds on opportunity-based conceptualisations of entrepreneurship that focus on the identification and exploitation of opportunities. The study investigates the importance of factors when evaluating opportunities and identifies distinct clusters of preferences for differing opportunities. Based on a conjoint analysis where importances and part worth utilities were calculated when assessing an entrepreneurial opportunity, significant differences appear in the importances associated with the business sector, capital intensity, technology maturity, market potential and return on investment potential. Moreover clustering is dependent on gender, academic background and principal work experience of respondents. A holistic conclusion of this study confirms not only that both opportunity dimensions and demographic factors are important, but that identifying levels of differences and differences in the degree of importances with unique constellations therein, is fundamental in understanding opportunity evaluation. The study contributes to the clustering of different types of opportunities to ensure the effective targeting of policies and services by government. Empirical evidence is mounting which demonstrates that there are more entrepreneurial opportunities in developing countries and that the higher number of entrepreneurial opportunities and demand for entrepreneurship in developing countries is indeed matched by higher rates of opportunity-driven entrepreneurs entering the market.
\end{abstract}

\section{Introduction}

Recent research finds that the matching of entrepreneurial talent with productive technologies and opportunities for growth is the essence for driving economic development (Naude, 2010). In emerging economies where growth is often the primary goal of organisations, opportunity recognition and innovation in small and medium enterprises (SMEs) can be particularly critical for firm profitability and survival (Antoncic \& Hisrich, 2001; Goosen, De Coning \& Smit, 2002). For businesses based in Africa, the challenge to participate in the global economy of the 21 st century will be to compete as world-class businesses where the focus is on high-value added human capital based on creativity and opportunity recognition leading to high-growth firms (Goedhuys \& Sleuwaegen, 2010; Luiz, 2006).

Since 1994, the South African government has acknowledged the important role in fostering an enabling environment for the creation and growth of small, medium and micro enterprises (SMME). The growth and development of the SMME business sector, has been identified by many stakeholders as being of utmost importance in an effort to create employment and address poverty (Department of Trade \& Industry, 2006). In particular, opportunity-driven entrepreneurship can drive structural transformation in both the modern and traditional sectors through innovation and the provision of intermediate inputs and services and by increasing employment and productivity (Gries \& Naude, 2010). An increasing pool of entrepreneurs is assumed to be linked to these beneficial outcomes. These outcomes are often shaped by the ability of entrepreneurs to recognise and evaluate business opportunities (Westhead, Ucbasaran \& Wright, 2009).

Opportunity-based conceptualisations of entrepreneurship emphasise that entrepreneurship research should focus on the entrepreneurial process, which is viewed largely as the identification and exploitation of opportunities (Ardichvili \& Cardozo, 2000, Venkataraman, 1997). Individuals are thought to identify opportunities because they possess uniquely different forms of knowledge or human capital (Venkataraman, 1997), and where entrepreneurial opportunities encompass a social learning process whereby new knowledge continuously emerges to resolve uncertainty inherent to each stage of opportunity development (Dimov, 2007 b). Moreover, the ability to identify opportunities is a cognitive task that allows some individuals, though not others, to identify opportunities (Corbett, 2007; Shane \& Venkataraman, 2000).

While there are a plethora of studies in South Africa focusing on SMME policy, hardly any scientific attention has been paid to how entrepreneurs recognize and exploit opportunities. Entrepreneurial support initiatives typically look at business and technical skills training but not at developing an entrepreneurial mindset to change levels of perceived opportunities. This caveat is important as opportunity focused SMMEs primarily respond to competitive forces and growth objectives and demonstrable returns (Hirsehsohn, 2008; van Zyl \& Mathur-Helm, 2007). Understanding opportunity recognition and exploitation 
behaviours would assist national policy makers who are trying to encourage more opportunity-focused entrepreneurial behaviour. Such a research undertaking is valuable as there is a dearth of consistent, comparable and comprehensive data on SMME activities in South Africa (Seda, 2007). Such knowledge gaps create a wide margin of potential error when estimating levels of unemployment and the design of appropriate support policies becomes very difficult (Seda, 2007).

Research in Africa as a whole, may be considered as valuable, as very few empirical studies have been previously conducted which focus on opportunity-based conceptualisations of entrepreneurship. The majority of research on opportunity-based entrepreneurship has been conducted in the United States, and with the relevance of international entrepreneurship being recognized (Jantunen et al. 2005), the importance of further interrogating opportunity recognition and evaluation in an emerging country context seems justifiable. Such investigations will allow researchers to compare and examine different opportunity evaluation preferences in similar environmental contexts.

In order to rationally embrace the value in emerging opportunities it is important that the nature of differing opportunities be understood (Thukral, Von Ehr, Walsh et al., 2008; Ucbasaran, Westhead \& Wright, 2001). By employing conjoint analysis, which requires respondents to make a series of judgments based on profiles from which their captured decision processes can be decomposed into its underlying structure (Saayman, Saayman \& Slabbert, 2011; Shepherd \& Zacharakis, 1997), we are able to empirically determine which criteria are significantly used in the decisions on an entrepreneurial task; consequently the objectives of this article are:

- to investigate the importance of factors when evaluating opportunities,

- to investigate respondents' inclination towards specific characteristics of opportunities,

- to differentiafe between the preferences in opportunity evaluation of various demographics,

- to identify distinct clusters of preferences for differing opportunities,

- to investigate whether such clusters have distinctive demographic characteristics.

\section{Theoretical overview}

The basic assumption underlying the economic theory of entrepreneurship is that in order to exist, entrepreneurship has to rely on undiscovered disequilibrium opportunities (Dutta \& Crossan, 2005). Discovering these disequilibrium spots seems to be a talent that is not equally shared by all (Kaish \& Gilad, 1991). Although one of the foremost characteristics distinguishing entrepreneurs from other groups in the population relates to the former's ability to identify market opportunities and to exploit them for the creation of business ventures (Casson, 1982; Knight, 1942;
Schumpeter, 1971), most economic theories have failed to explain convincingly why entrepreneurs engage with opportunities. In the traditional neoclassical yiew, entrepreneurship is the mystical element that delivers external shocks to a state of equilibrium in the marketplace by introducing new products and services (Alvarez \& Busenitz, 2001; Ardichvili, Cardoza \& Ray, 2003).

Scholars in the field of entrepreneurship have long been interested in understanding the nexus of opportunities and entrepreneurs and have published a wide variety of answers. Shane and Venkataraman (2000) make a compelling argument that entrepreneurial opportunity recognition and evaluation are constructs that fall within the unique domain of entrepreneurship and should be the central focus of research in the field. Shane and Venkataraman (2000) have argued that entrepreneurship is an activity that involves the nexus of two phenomena: the presence of lucrative opportunities and the presence of enterprising individuals. A myopic focus on either the individual or the opportunity alone, without regard to the other, involves an incomplete analysis. The logical basis for individual-opportunity nexus (ION) is the idea that entrepreneurial opportunities emerge from market disequilibrium or, more specifically, from the differences people have in their expectations, beliefs, awareness, and/or knowledge about the relative (future) value of resources (Kirzner, 1979; Plummer, Haynie \& Godesiabois, 2007). Shane and Venkataraman (2000: 220) suggest that "because people possess different beliefs (because of a lucky hunch, superior intuition, private information, etc.), they make different conjectures about the price at which markets should clear, or about what possible new markets could be created in the future". Empirical research to date has shown that the ability to identify opportunities is related to such human capital variables as education, work experience, entrepreneurial experience (Davidsson \& Honig, 2003), prior knowledge (Shane, 2000), prior knowledge of customer problems (Shepherd \& DeTienne, 2005), experiential knowledge (Dimov, 2007a), entrepreneurial human capital (Ucbasaran, Westhead \& Wright, 2008), and prior business ownership experience (Westhead, Ucbasaran \& Wright,2009).

The concern here, is not with all market opportunities, but rather entrepreneurial opportunities, which are conceptualized as situations that entail the discovery of new means-ends relationships in which new goods, services, raw materials, and organizing methods are introduced to generate economic value (Casson, 2005; Companys \& McMullen, 2007; Shane \& Venkataraman, 2000). As a result, entrepreneurial opportunities represent hitherto unknown ways of doing things (Kirzner, 1973). Although most scholars have generally agreed with Shane and Venkataraman's conceptualization of entrepreneurial opportunities, they have disagreed on the sources and nature of these opportunities. Synthesizing the strategic management and entrepreneurship literatures, McMullen, Plummer and Acs (2007), characterize three schools regarding the sources and types of opportunity: (1) the economic school, (2) the cultural cognitive school, and (3) the socio-political school. The economic school focuses on 
the objective dimensions of knowledge and information, and attributes the existence of entrepreneurial opportunities to the distribution (or lack thereof) of information regarding material opportunities in society. The cultural cognitive school, while sharing an emphasis on knowledge and information, takes a view that it is the emergence of a subjective, shared meaning of knowledge that constructs opportunity. The socio-political school is built on the notion that opportunities are objective in the sense that they are social network structures and yet subjective, given their exploitation depends on the entrepreneur's political skills and ability to persuade others as part of successful commercialization. In a similar vein, Companys and McMullen (2007) classify the different types of entrepreneurial opportunities as economic, cultural, cognitive and socio-political opportunities, where several sub-types within these categories can also be identified depending on whether the perspective addresses the supply or demand side of a particular production function.

Additionally, many researchers have developed conceptual models of the opportunity recognition process (e.g., Bhave, 1994; Gaglio \& Katz, 2001; Lumpkin, Hills \& Shrader, 2004; Singh, 2000). Opportunity recognition and evaluation tends to include three distinct processes: (1) sensing or perceiving market needs and/or underemployed resources, (2) recognizing or discovering a fit between particular market needs and specified resources, and (3) creating a new fit between heretofore separate needs and resources in the form of a business concept (Hills \& Singh, 2004). Similarly, Davidsson and Honig (2003) identify four opportunity identification processes: (1) learn/replicate, learn/innovate, (3) learn/acquire, and (4) innovate/educate. Moreover researchers show that differences in human capital are related to the selection and application of different opportunity identification processes (Lumpkin, et al., 2004). In general, people discover opportunities that others do not identify for two reasons, (1) they have better access to information about the existence of the opportunity, and (2) they are better able than others to recognize opportunities, given the same amount of information about it, because they have superior cognitive capabilities (Krueger, 2000). Recent studies have identified crosscultural entrepreneurial competence as a prerequisite for identifying international business opportunities (Baron, 2004, 2006; Muzychenko, 2008; Wennberg \& Holmquist, 2008).

Opportunity recognition has also been modelled on theory from the creativity and psychology literature (Hills, Schrader \& Lumpkin, 1999; Pretorius, Millard \& Kruger, 2005). Here, opportunity recognition may be seen as a series of steps involving iteration of creative thinking, and/or as the creative stage of the entrepreneurial model (Bhave, 1994). This creation perspective is consistent with the ontological perspective that opportunities are a product of one's mind. Lumpkin, et al., (2004) argue that the creation of successful businesses follows successful opportunity development and also involves entrepreneur's creative work. This opportunity development process includes recognition of an opportunity, its evaluation, and development (Shane \& Venkataraman, 2000).

The generation and refinement of opportunity ideas typically occurs at a pre-venture stage, i.e., before there is any formal organization around the pursuit of these ideas. Given that the ideas passing through this stage pertain to an indeterminate future enshrined in Knightian uncertainty and that an ex-ante judgment of their eventual commercial success is thus unreliable, their perceived feasibility and potential are propped up by individual beliefs (Dimov, 2007a). As Casson (2005) points out, entrepreneurial decisions are by definition judgmental in the sense that the choices made in the current period are based on an individual's belief or interpretation of what the future is to hold; such beliefs and conjectures about the future, however, are based primarily on the information and knowledge initially at hand. The point, however, is that the choices and actions of individual entrepreneurs - a particular domain of management scholars, especially concerning the entrepreneur's cognitive dimensions - must be understood in the context of the broader environmental conditions - a particular domain of economists and policy thinkers - and vice versa.

Corbett (2007) demonstrates that learning asymmetries not only exist, but they have a profound effect on why some individuals discover opportunities while others do not. The knowledge and learning habits of potential entrepreneurs, rather than being universally effective in the generation and development of opportunities through further action, are effective only in some situations and are detrimental in others. This puts forth the overarching notion that the generation of opportunity ideas can occur in qualitatively different contexts and thus can involve different types of insight. Based on the information available to potential entrepreneurs on existing or emerging customer needs, and on products that can serve these needs, ideas are generated through convergent or divergent insights.

Having experience and knowledge within an industry facilitates entrepreneurs ${ }^{*}$ recognition of market gaps and assessment of the market potential of the new venture (Singh, 2000). Social encounters are another source of venture ideas and these can lead to opportunity recognition and exploitation. Research indicates that certain opportunity recognition behaviours and actions help reduce the liability of newness and improve the chances for success. Failures and false starts are a normal part of the opportunity recognition process, and the knowledge gained from such experiences often leads to future gains that are more solid (Hills \& Singh, 2004). The role of information and cognitive processes as well as research-mentors and participation in professional forums can all assist in identifying and evaluating opportunities (Ozgen \& Baron, 2007). Perception and interpretation are in turn guided by the mental representations or cognitive maps that individuals develop of the particular domain. Because these maps differ in their structure and complexity across individuals, different individuals are likely to interpret the same stimulus differently (Walsh, 1988). At the basis of such differences in 
map structures and in resulting interpretations lie one's domain-specific knowledge and associated knowledge structures (Dimov, 2007a). Individuals in decision-making situations typically draw upon scripts or knowledge structures to make decisions to act. Some of these scripts are well developed (expert scripts) while others (novice scripts) are not as fully developed, resulting in information processing-based thinking errors (Busenitz \& Lau, 1996; Urban, 2010).

Many researchers concentrate on discussion and appraisal of discovery and implementation of opportunity. Evaluation mysteriously disappears. In contrast in determining the essence of what entrepreneurs do, in their capacity as entrepreneurs, evaluation is both fundamental and distinctive and is, therefore, the most important of the various components of entrepreneurial opportunity. So, at the heart of what might be called entrepreneurial capacity is the ability to evaluate an opportunity, not simply the ability to discover or exploit it. Opportunities are evaluated at each stage of their development, although the evaluation may be informal or even unarticulated (Ardichvili \& Cardozo, 2000). Understanding the notion of exploitation of opportunity provides insights as to the origins of opportunity. Casson (2005) makes the assumption that the exploitation phase of the entrepreneurial process includes a set of choices that equates to the execution of competitive strategy. Under this perspective opportunities are real, independent of the entrepreneurs who perceive them, and only individuals with appropriate qualities will perceive them.

These insights represent different starting points for the subsequent evaluation and interpretation of the ideas as they involve drawing different possibilities and inferences from the information at hand (Dimov, 2007b). Taking cognizance of variation in entrepreneurial ability and the differences in venture idea characteristics, understanding preferences and variation is necessary for studies in opportunity recognition and evaluation (Samuelsson \& Davidsson, 2009).

\section{Hypotheses formulation}

Central to the diversity inherent in entrepreneurship, is that variations exist among opportunities. As gleaned from the abovementioned research, often the differences in the quality of entrepreneurs, results in differences in opportunities pursued. For example, an entrepreneur who creates one specific type of business opportunity might not even grasp the significance of other types of business opportunities. To do so would require a different set of aspirations, personalities, intentions, knowledge, and skills (Lee \& Venkataraman, 2006).

It is clear that the heterogeneity of the population is a fundamental factor in theories of entrepreneurship. If everyone were fundamentally the same then random variation would be the obvious explanation as to why some people become entrepreneurs and other do not. The evidence suggests, however, that there are systematic factors at work (Casson, 2005), which is in line with the major premise of this paper. Drawing on opportunity-based conceptualisations of entrepreneurship, which emphasise the heterogeneity in identification and exploitation of opportunities (Dimov \& Milanov, 2010) we formulate hypotheses to understand the evaluation process in terms of preferences and clusters of particular entrepreneurial opportunities. Specifically, we examine the importance and inclination of attributes that respondents attach to the assessing of opportunities. We further try to differentiate between opportunity preferences in terms of various demographic variables and subsequently identify distinct clusters of preferences for differing entrepreneurial opportunities.

The first hypothesis is linked to Casson's (2005) assumption that the exploitation of the opportunity includes a set of choices that equates to the execution of competitive strategy, which includes deciding the best strategy for exploiting the opportunity given the characteristics of the opportunity. In Austrian theory, it is the prospect of profit from an opportunity that motivates the search that leads to discovery (Casson \& Wadeson, 2007; Kirzner, 1973). The opportunity must be seen as a feasible, profit-seeking, potential venture that provides an innovative new product or service to the market, improves on an existing product/service, or imitates a profitable product/service in a less-than-saturated market (Singh, 2000).

H1: There is a significant difference in the degree of
importance in terms of business sector, capital intensity,
technological maturity, market potential and return on
investment potential when assessing an entrepreneurial
business opportunity.

Additionally as entrepreneurs exploit opportunities to create and deliver value, to capture the value in emerging opportunities it is important that the nature of differing opportunities be calculated in terms of their utility values.

\section{H 2: There is a significant difference in the mean part worth utilities attributable to entrepreneurial opportunities (a) in different business sectors, (b) in those that are capital versus labour intensive, (c) in those with differing technology maturity, (d) where there is a significant positive correlation between the mean part worth utilities attributable to entrepreneurial opportunities and the expected market growth, and (e) their return on investment potential.}

Building on the premise that individuals are thought to identify opportunities because they possess uniquely different forms of human capital (Ucbasaran et al., 2008; Venkataraman, 1997), our third hypothesis relates to the differences in evaluation decisions, reflecting individual differences in evaluating the benefits or risks associated with prospective ventures. It is also noted that such differences arise, in part, from differences in how individuals interpret and react to the market information brought by prospective ventures. Interpretation and reaction are thus endogenous to the decision making process - they 
are largely dependent on decision makers' expertise and their social standing. Dimov, Shepherd and Sutcliffe (2007) demonstrate how the inclusion of psychological and sociological constructs can enrich the study of venture capital investment allocation decisions. Previous education and work experience has been found to be associated with selection into entrepreneurship and various measures of success (e.g. Dickson, Solomon \& Weaver, 2008). This suggests possible relationships between opportunity preferences and these variables that, together with demographic variables, are explored in the following hypotheses.

$H$ 3: There is a significant difference in opportunity preferences on (a) the gender (b) the academic backgroumd (c) the family status (d) previous work experience (e) professional training, and $(f)$ the age of the respondent.

Recognising the unique nature of individuals, in unique circumstances, undertaking unique activities to start unique businesses (Gartner, 2008) we further hypothesize that since individuals are heterogeneous in their assessment of entrepreneurial opportunities, they may therefore be clustered on the basis of their preferences. This is in line with the archetype perspective which suggests that a wide variety of factors or characteristics tend to cluster together, as gestalts. A gestalt would be a form or constellation of specific attributes that would characterise a different type of the phenomenon (Gartner, 2008).

H 4: Cluster membership is dependent on (a) the gender (b) the academic background (c) the family status (d) previous work experience (e) professional training, and (f) the age of the respondent.

\section{Methodology}

\section{Sampling}

The research sample was based on a population of nascent entrepreneurs who are actively committing resources to start a business that they expect to own themselves, but who have not reached the birth event as yet (Bosma \& Levie, 2009). Additionally, respondents had to meet the criteria of individually making venture creation decisions and assessing opportunities themselves - hence the term 'principal investor'. It was felt that by not including the term 'investor' respondents may not have properly included risk in their assessment of opportunity. Investors, especially 'informal investors' in transition economies play an important role in determining entrepreneurial behaviour. Moreover informal investors are sensitive to start-up skills and good business opportunities (Jeffrey, York \& Venkataraman, 2010; Lu \& Tao, 2008). Data was gathered over a two year period in the greater Johannesburg area from respondents attending a series of business and entrepreneurship symposia and training programs. The survey was administered electronically (sending emails, with periodic reminders). Based on the research procedure and stated selection criteria, 306 respondents qualified as the final sample.

\section{Survey instrument}

The survey instrument was based on a conjoint design. The basis of conjoint analysis is that participants' utilities for any given multi-attribute alternative are the aggregate of the partial utilities of the attributes that make up that alternative. Survey participants' partial utilities for attributes can be estimated by obtaining their preferences for a series of carefully designed multi-attribute alternatives (conjoint tasks). Using least squares regression, the dependent variable is the preference ratings and the independent variables are dummy variables corresponding to each attribute and the estimated part worth utilities are the regression coefficients.

In this instance, the conjoint survey items are rooted in criteria for evaluating venture opportunities (e.g., Hisrich, 2000; Kirzner, 1979; Timmons, 1994), as discussed in the theoretical section of this paper. These opportunity dimensions include attributes of the business sector, capital intensity, technology, market growth rate, and return on investment potential. The breakdowns for each category are based on the attractiveness of each criterion with the highest potential representing $25 \%$; the medium potential is $10 \%$ and the lowest potential at $0 \%$ (Timmons, 2002). Similar to other studies, for all attributes, low does not mean that the level on this attribute is zero or negative; rather it is a low positive (Haynie et al., 2009). A conjoint questionnaire using a partial factorial design survey, reflecting these attributes and attribute levels is shown in Table 1. The recommended number of conjoint tasks was given as 42 and the absolute minimum number of tasks was given as 14 . It was decided to opt for 30 pair wise comparison conjoint tasks using a nine point interval level scale, with verbal anchors.

Table 1: Attributes and levels used for conjoint survey

\begin{tabular}{ll}
\hline Attributes & Attribute levels \\
\hline Business sector & Information \& communications \\
technology & Biotechnology \\
& Logistics, transportation \& distribution \\
& Fast food franchising \\
& Hospitality \& tourism \\
& Textiles, clothing \& accessories \\
& Business consulting services \\
& Capital intensive \\
Capital intensity & Labour intensive \\
& Innovative and unproven technology \\
Technology & Proprietary but proven technology \\
& Conventional and familiar technology \\
& $25 \%$ expected market growth \\
Market growth rate & $10 \%$ expected market growth \\
& $0 \%$ expected market growth \\
Return on investment & $20 \%$ return on investment potential \\
potential & $10 \%$ return on investment potential \\
& $5 \%$ return on investment potential
\end{tabular}


The survey was distributed on a USB mass storage device and administered electronically, as illustrated in Figure 1. The number and complexity of the conjoint tasks may be regarded as relatively onerous. However, due to the qualifications and competencies of the respondents, and as the survey could be carried out in the respondents own work, study or home environments, respondent fatigue was not expected to detrimentally affect survey reliability. The survey was piloted with an initial group of respondents from the sample population; as no changes to the questionnaire were indicated, the responses of the pilot sample were included in the final analysis.

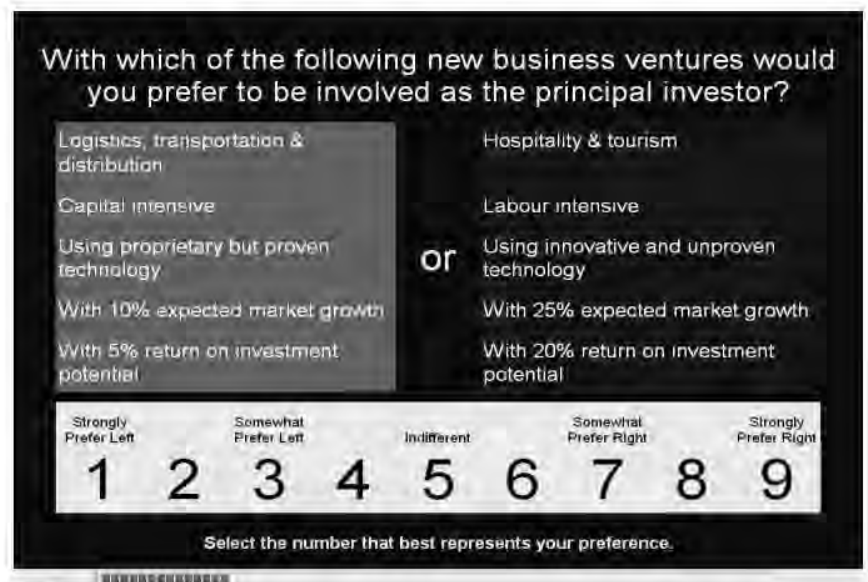

Figure 1: Pairwise comparison conjoint task survey screen

\section{Data analysis}

The conjoint part worth utilities were estimated by Sawtooth Software SMRT (Sawtooth Software, 2002) using the method of ordinary least squares, which is appropriate for analysing interval level conjoint data. Part worth utilities were calculated using zero-centred differences; that is, the sum of the part worth utilities for each attribute is equal to zero. Conjoint importances were calculated such that the sum across all attributes of the differences between the best and worst attribute levels is equal to 100 . This results in interval level part worth utilities and ratio level conjoint importances.

The resultant conjoint importances and part worth utilities were analysed using a variety of nonparametric tests due to the non-normality of the distributions. These tests are summarised in Table 2. Due to the exploratory nature of the research, a significance level $(\alpha)$ of $5 \%$ was considered appropriate for all hypothesis tests carried out.

\section{Results}

Demographic results reveal that the sample comprised predominantly males $(69.6 \%$ ), with the largest proportions having a commerce, law or business educational background $(42.5 \%)$, who are unmarried $(42.5 \%)$ and have gained their principal business experience in businesses of more than 50 employees $(66.0 \%)$. The median age of the respondents was 31.

Table 2: Hypothesis tests for analysing conjoint data

\begin{tabular}{lll}
\hline Hypothesis & Data & Hypothesis test(s) \\
\hline Hypothesis 1 & $\begin{array}{l}\text { Conjoint } \\
\text { importance }\end{array}$ & Friedman's ANOVA by ranks \\
Hypothesis 2 & $\begin{array}{l}\text { Conjoint } \\
\text { utilities }\end{array}$ & $\begin{array}{l}\text { Friedman's ANOVA by ranks, } \\
\text { Wilcoxon signed-rank test; } \\
\text { Spearman's rank correlation } \\
\text { coefficient }\end{array}$ \\
Hypothesis 3 & $\begin{array}{l}\text { Conjoint } \\
\text { importances } \\
\text { and utilities; } \\
\text { demographics }\end{array}$ & $\begin{array}{l}\text { Welch unequal variance t-test, } \\
\text { one-way analysis of variance, } \\
\text { Kruskal Wallis ANOVA, or } \\
\text { Spearman's rank correlation } \\
\text { coefficient }\end{array}$ \\
& \multicolumn{2}{c}{$\begin{array}{l}\text { Cluster means } \\
\chi^{2} \text { test of independence; Kruskal }\end{array}$} \\
& $\begin{array}{l}\text { of conjoint } \\
\text { importances } \\
\text { and utilis ANOVA } \\
\text { Cluster } \\
\text { membership; } \\
\text { demographics }\end{array}$ & \\
\hline
\end{tabular}

\section{Overall conjoint importances}

The conjoint importances of attributes, averaged across all respondents, are illustrated in Figure 2. Although the differences between the conjoint importances of the attributes is evident, the Friedman's ANOVA by ranks (the non-parametric equivalent to the repeated measures withinsubject ANOVA) was carried out on the importances. The result of the Friedman's ANOVA by ranks is as follows: $Q$ $=584.75$, d.f. $=4$, p-value $<0.0001$. From this it is concluded that there is a significant difference in the importances associated with the business sector, capital intensity, technology maturity, market potential and return on investment potential when assessing an entrepreneurial opportunity.

The business sector in which the venture exists is the principal determinant of its attractiveness to respondents, followed closely by the market growth rate. The importance of the potential return on investment was substantial, being consistent with the contextualisation of the conjoint task as an investment decision. The capital intensity and technology were not found to be substantial determinants of the attractiveness of a new business venture. 


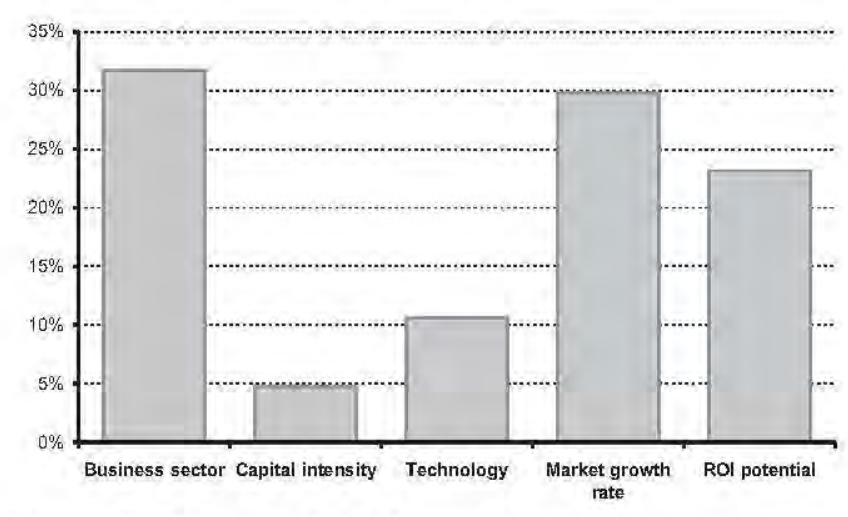

Figure 2: Mean conjoint importances

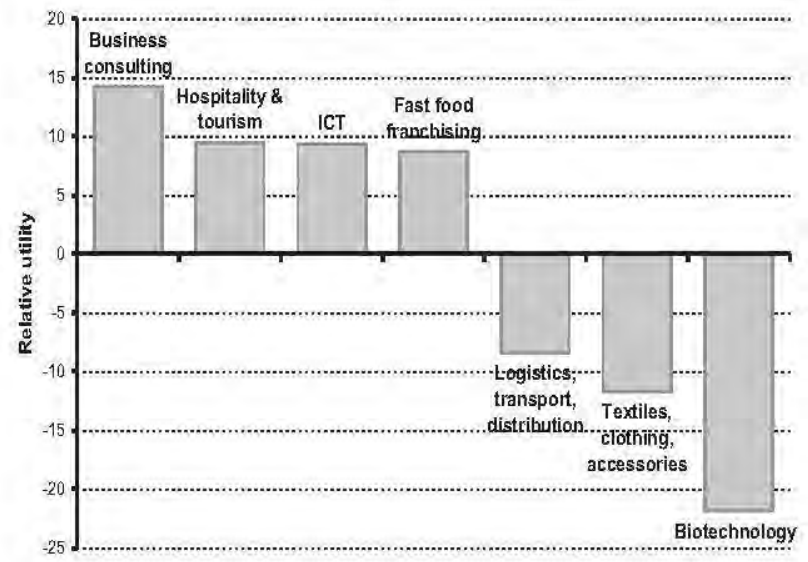

Figure 3a. Business sector

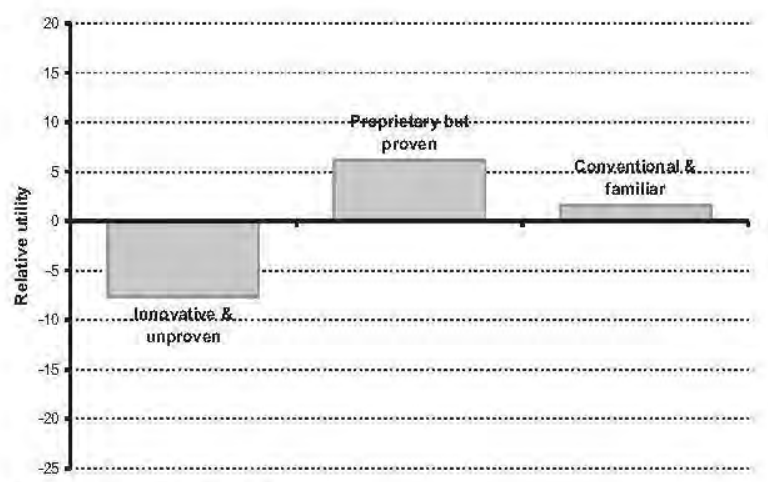

Figure 3c. Technology

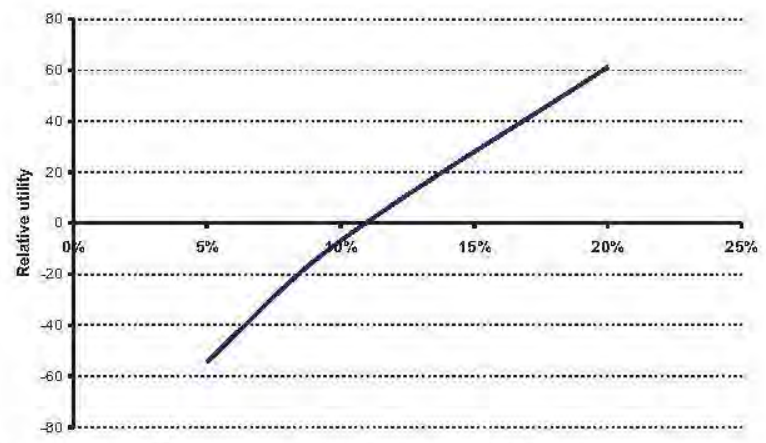

Figure 3e. Return on Investment Potential
Figures 3a-3e display the overall conjoint part worth utilities, broken down per attribute level as per $3 a, 3 b, 3 c$, $3 \mathrm{~d}, 3 \mathrm{e}$. Because the distributions of the part worth utilities were not normal, non-parametric tests were used to determine whether their means were dependent on the level of the attributes: Spearman's rank correlation coefficient applied where the attribute levels were numeric, the Wilcoxon signed-rank test applied where there were two nominal attribute levels, and Friedman's ANOVA by ranks applied where there were more than two nominal attribute levels. The results given in Table 3 indicate that there are significant differences in the means for all attributes apart from the capital intensity attribute.

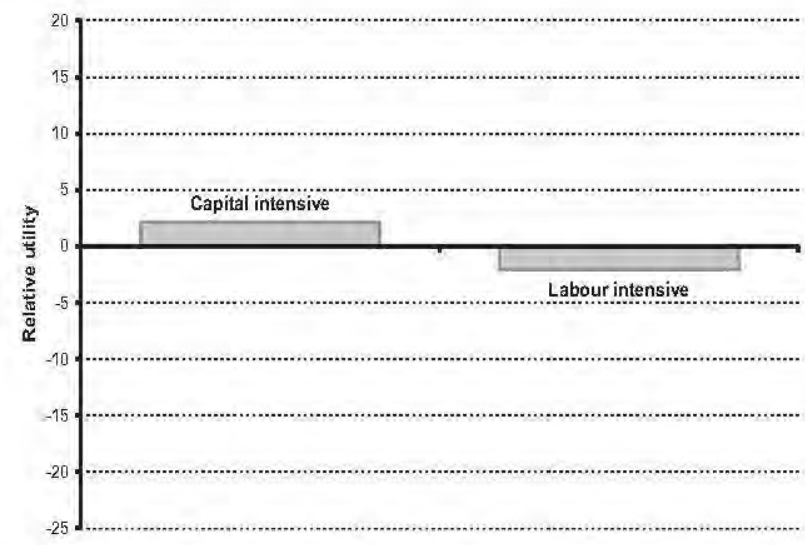

Figure 3b. Capital intensity

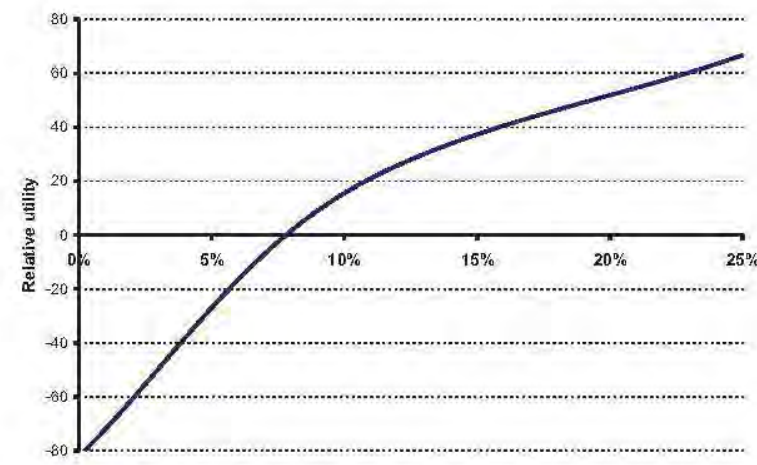

Figure 3d. Market Growth Rate 
Table 3: Significance of attributes of entrepreneurial opportunities

\begin{tabular}{llll}
\hline Attribute & Statistical test & Test statistic & p-value \\
\hline Business sector & Friedman's ANOVA by ranks & $\mathrm{Q}=88.1989$ & $<0.0001$ \\
Capital intensity & Wilcoxon signed-rank test & $\mathrm{z}=1.626$ & 0.1040 \\
Technology & Friedman's ANOVA by ranks & $\mathrm{Q}=11.2614$ & 0.0036 \\
Market growth rate & Spearman's rank correlation coefficient & $\mathrm{r}_{\mathrm{s}}=0.8791$ & $<0.0001$ \\
ROI potential & Spearman's rank correlation coefficient & $\mathrm{r}_{\mathrm{s}}=0.8633$ & $<0.0001$ \\
\hline
\end{tabular}

\section{Differences in conjoint importances between} demographic groups demographic groups, depending on the nature and characteristics of the independent variable.

Table 4 details the appropriate hypothesis tests used to analyse differences in conjoint importances between

Table 4: Selection of statistical test based on independent variable characteristics

\begin{tabular}{|c|c|c|c|c|c|}
\hline Independent variable & $\begin{array}{c}\text { Numeric or } \\
\text { ordinal }\end{array}$ & \multicolumn{4}{|c|}{ Categorical (nominal level) data } \\
\hline Categories & & \multicolumn{2}{|c|}{ Two categories } & \multicolumn{2}{|c|}{ More than two categories } \\
\hline Criteria & Non-normal & Equal variances & $\begin{array}{l}\text { Unequal } \\
\text { variances }\end{array}$ & $\begin{array}{l}\text { Large samples; } \\
\text { normal; equal } \\
\text { variances }\end{array}$ & $\begin{array}{l}\text { Small samples; } \\
\text { non-normal; } \\
\text { unequal variances }\end{array}$ \\
\hline Statistical test & $\begin{array}{c}\text { Spearman's rank } \\
\text { correlation } \\
\text { coefficient }\end{array}$ & $\begin{array}{c}\text { Equal variance } \\
\text { t-test }\end{array}$ & $\begin{array}{c}\text { Aspin-Welch } \\
\text { unequal variance } \\
\text { test }\end{array}$ & $\begin{array}{l}\text { One way } \\
\text { ANOVA }\end{array}$ & $\begin{array}{l}\text { Kruskal-Wallis } \\
\text { one-way ANOVA }\end{array}$ \\
\hline
\end{tabular}

The results of the hypothesis tests of differences in conjoint importances between demographic groups are given in Table 5. The hypothesis tests that were applied have been indicated using distinguishing symbols, and several significant differences (at $\alpha=5 \%$ ) have been highlighted.
Significant differences in conjoint importances between demographic groups are found for sex and academic background on three of the five attributes: business sector, capital intensity, and ROI potential.

Table 5: Significance of conjoint importances across demographic groups

\begin{tabular}{|c|c|c|c|c|c|c|}
\hline & Gender & $\begin{array}{l}\text { Academic } \\
\text { background }\end{array}$ & Family status & Work experience & $\begin{array}{l}\text { Professional } \\
\text { training }\end{array}$ & Age \\
\hline Business sector & $\begin{array}{l}0.0022 * \\
I_{q}>I_{\gamma}^{*}\end{array}$ & $\begin{array}{l}0.0117 \ddagger \\
\mathrm{I}_{\text {Art }} \gg \mathrm{I}_{\text {Medicine }}\end{array}$ & $0.8014 \ddagger$ & $0.7433 \mp$ & $0.6667 \dagger$ & \multirow{5}{*}{$\begin{array}{l}\mathbf{0 . 0 4 3 8 * *} \\
\mathrm{r}_{\mathrm{s}}=0.1153 \\
0.6250^{* *} \\
\mathrm{r}_{\mathrm{s}}=0.0281 \\
0.6152 * * \\
\mathrm{r}_{\mathrm{s}}=-0.0288 \\
0.4489 * * \\
\mathrm{r}_{\mathrm{s}}=-0.0435 \\
0.1436 * * \\
\mathrm{r}_{\mathrm{s}}=-0.0838\end{array}$} \\
\hline Capital intensity & $\begin{array}{l}0.0169 \dagger \\
I_{\phi}>I_{\delta}\end{array}$ & $\begin{array}{l}0.0315 \ddagger \\
I_{\text {Art }} \gg I_{\text {Seience }}\end{array}$ & $0.1050 \ddagger$ & $0.8788 \mp$ & $0.1396 *$ & \\
\hline Technology & $0.1873+$ & $0.1050 \ddagger$ & $0.2620 \ddagger$ & $0.5387 \ddagger$ & $0.6507 \dagger$ & \\
\hline $\begin{array}{l}\text { Market growth } \\
\text { rate }\end{array}$ & $0.8059 \dagger$ & $0.2341 \ddagger$ & $0.4778 \&$ & $\begin{array}{l}\mathbf{0 . 0 3 5 8} \ddagger \\
\mathrm{I}_{\text {Micre }} \gg \mathrm{I}_{\text {Med }}\end{array}$ & $0.4479 \dagger$ & \\
\hline ROI potential & $\begin{array}{l}<\quad 0.0001 * \\
I_{0}<I_{0}\end{array}$ & $\begin{array}{l}0.0016 \$ \\
I_{\text {Mediome }} \gg I_{\text {Art }}\end{array}$ & $0.1124 \ddagger$ & $0.5254 \ddagger$ & $0.3824 \dagger$ & \\
\hline $\begin{array}{l}\text { * Aspin- } \\
\text { \# Kruska } \\
* * \text { Spear }\end{array}$ & $\begin{array}{l}\text { Welch unequal } \\
\text {-Wallis one-way } \\
\text { man's rank corre }\end{array}$ & $\begin{array}{l}\text { riance test } \\
\text { ANOVA } \\
\text { ation coefficient }\end{array}$ & $\begin{array}{l}\text { † Equal- } \\
\& \text { One wa }\end{array}$ & $\begin{array}{l}\text { iance } t \text {-test } \\
\text { ANOVA }\end{array}$ & & \\
\hline
\end{tabular}

Differences in conjoint part worth utilities between demographic groups

Table 6 gives the results of the variety of hypothesis tests used to analyse differences in conjoint part worth utilities between demographic groups. The appropriate hypothesis test has been determined using the same criteria that were used for testing the conjoint importances, as detailed in Table 4. Distinguishing symbols have been used to indicate the hypothesis tests that were applied, and significant differences (at $\alpha=5 \%$ ) have been highlighted. 
Table 6: Significance of conjoint part worth utilities across demographic groups

\begin{tabular}{|c|c|c|c|c|c|c|}
\hline Sector & Gender & $\begin{array}{l}\text { Academic } \\
\text { background }\end{array}$ & Family status & Work experience & $\begin{array}{l}\text { Professional } \\
\text { training }\end{array}$ & Age \\
\hline $\begin{array}{l}\text { Information \& } \\
\text { communications } \\
\text { technology }\end{array}$ & $0.3626 *$ & $0.2140 \ddagger$ & $\begin{array}{l}0.0355 \ddagger \\
\mathrm{U}_{\text {Kids }} \gg \mathrm{U}_{\mathrm{Mar}}\end{array}$ & $0.9589 \ddagger$ & $0.4731 \dagger$ & $\begin{array}{l}0.5835 * * \\
\mathrm{r}_{\mathrm{s}}=0.0315\end{array}$ \\
\hline Biotechnology & $\begin{array}{l}0.0044 * \\
\mathrm{U}_{\phi}<\mathrm{U}_{\AA}\end{array}$ & $\begin{array}{l}0.0001 \ddagger \\
\mathrm{U}_{\mathrm{Med}} \gg \mathrm{U}_{\text {Arts }}\end{array}$ & $0.9750 \ddagger$ & $0.7678 \ddagger$ & $0,2108 \dagger$ & $\begin{array}{l}0.1105 * * \\
\mathrm{r}_{\mathrm{s}}=0.0914\end{array}$ \\
\hline $\begin{array}{l}\text { Logistics, } \\
\text { transportation \& } \\
\text { distribution }\end{array}$ & $\begin{array}{l}0.0002 \dagger \\
\mathrm{U}_{q}<\mathrm{U}_{\hat{\partial}}\end{array}$ & $0.3834 \$$ & $0.3774 \$$ & $0.1554 t$ & $0.7162 \dagger$ & $\begin{array}{l}0.4508 * * \\
r_{s}=-0.0433\end{array}$ \\
\hline $\begin{array}{l}\text { Fast food } \\
\text { franchising }\end{array}$ & $0.5684 \uparrow$ & $0.7920 \ddagger$ & $0.4326 \ddagger$ & $0.4250 \ddagger$ & $0.1822 \dagger$ & $\begin{array}{l}0.6816 * * \\
r_{s}=0.0235\end{array}$ \\
\hline $\begin{array}{l}\text { Hospitality \& } \\
\text { tourism }\end{array}$ & $0.2269 *$ & $0.2361 \ddagger$ & $0.2595 \ddagger$ & $0.9023 \ddagger$ & $0.7745 \dagger$ & $\begin{array}{l}0.4261 * * \\
\mathrm{r}_{\mathrm{s}}=0.0457\end{array}$ \\
\hline $\begin{array}{l}\text { Textiles, clothing \& } \\
\text { accessories }\end{array}$ & $\begin{array}{l}0.0295 * \\
U_{\phi}>U_{g}\end{array}$ & $0.5097 \$$ & $0.9492 \ddagger$ & $0.5504 \ddagger$ & $0.3605 \dagger$ & $\begin{array}{l}0.1646 * * \\
r_{s}=-0.0796\end{array}$ \\
\hline $\begin{array}{l}\text { Business consulting } \\
\text { services }\end{array}$ & $\begin{array}{l}0.0006 * \\
\mathrm{U}_{q}>\mathrm{U}_{8}\end{array}$ & $\begin{array}{l}0.0001 \ddagger \\
\mathrm{U}_{\text {Ats }} \gg \mathrm{U}_{\text {Med }}\end{array}$ & $0.4988 \neq$ & $\begin{array}{l}\mathbf{0 . 0 3 5 1} \ddagger \\
\mathrm{U}_{\text {Med }} \gg \mathrm{U}_{\text {Micro }}\end{array}$ & $0.0817 \dagger$ & $\begin{array}{l}\mathbf{0 . 0 1 0 4} * * \\
r_{8}=-0,1463\end{array}$ \\
\hline $\begin{array}{l}\text { Capital / Labour } \\
\text { intensive }\end{array}$ & $0.3146 *$ & $0.1530 \ddagger$ & $0.8043 \ddagger$ & $0.4436 \ddagger$ & $0.5472 *$ & $\begin{array}{l}0.4855 * * \\
r_{s}=0.0400\end{array}$ \\
\hline $\begin{array}{l}\text { Innovative and } \\
\text { unproven } \\
\text { technology }\end{array}$ & $0.8940+$ & $0.4714 \neq$ & $0.3051 \ddagger$ & $0.8589 \ddagger$ & $0.6929 \dagger$ & $\begin{array}{l}0.7145 * * \\
\mathrm{r}_{\mathrm{s}}=-0.0536\end{array}$ \\
\hline $\begin{array}{l}\text { Proprietary but } \\
\text { proven technology }\end{array}$ & $0.3632 \dagger$ & $0.8283 \ddagger$ & $0.9175 \&$ & $0.8245 \$$ & $0.5663 \uparrow$ & $\begin{array}{l}0.0845 * * \\
\mathrm{r}_{\mathrm{s}}=0.0988\end{array}$ \\
\hline $\begin{array}{l}\text { Conventional and } \\
\text { familiar technology }\end{array}$ & $0.5025 *$ & $0.1770 \$$ & $0.2601 \S$ & $0.2558 \ddagger$ & $0.9648 \dagger$ & $\begin{array}{l}0.1843 * * \\
r_{s}=-0.0761\end{array}$ \\
\hline
\end{tabular}

\begin{tabular}{lll}
\hline Notes: & $*$ Aspin-Welch unequal variance test & † Equal-variance t-test \\
& \$ Kruskal-Wallis one-way ANOVA & \$ One way ANOVA \\
& $* *$ Spearman's rank correlation coefficient &
\end{tabular}

At the level of attributes, as displayed in Table 6, significant differences in conjoint part worth utilities between demographic groups are detected for gender and academic background in the biotechnology, logistics, textiles and business consulting business sectors. Few other significant differences in conjoint part worth utilities across demographic groups are detected.

\section{Preference based clusters}

A K-means cluster analysis was carried out using NCSS (Hintze, 2001). Based on the scree plot (Cattell, 1966) five clusters were selected. The mean conjoint importances and part worth utilities per cluster were initially calculated (not shown due to space constraints). It is noted that the percent of variation, being the sum of squared differences as a percentage of the sum of squared differences with no clustering, remains $65.95 \%$ after the $\mathrm{K}$-means clustering; that is, approximately two-thirds of the variability in the response data remains unexplained.

Hypothesis tests have been carried out to determine the independence of clusters and demographic groups, the results of which are given in Table 7 . It is shown that clustering is dependent on gender, academic background and principal work experience of respondents, but independent of their family status, professional training, and age. The preferences and demographic characteristics of the clusters are specified below and named accordingly. The cluster labels are based on combined interpretations of the results in Tables 6 and 7 . 
Table 7: Hypothesis tests of independence of clusters and demographic groups

\begin{tabular}{|c|c|c|c|c|}
\hline Demographic variable & Statistical test & Test statistic & Degrees of freedom & $\mathrm{p}$-value \\
\hline Gender & $x^{2}$ independence & $\chi^{2}=28.30$ & d.f. $=4$ & $<0.0001$ \\
\hline Academic background & $x^{2}$ independence & $x^{2}=46.96$ & d.f. $=16$ & $<0.0001$ \\
\hline Family status & $x^{2}$ independence & $x^{2}=1.77$ & d.f. $=8$ & 0.9873 \\
\hline Work experience & $x^{2}$ independence & $x^{2}=25.45$ & d.f. $=12$ & 0.0128 \\
\hline Professional training & $x^{2}$ independence & $x^{2}=3.08$ & d.f. $=4$ & 0.5438 \\
\hline Age & Kruskal Wallis & $\mathrm{H}=1.23$ & d.f. $=4$ & 0.8730 \\
\hline
\end{tabular}

Cluster 1 - 'Market growth focused opportunity'

- Seeking market growth potential

- Preference for innovation and unproven technology

- Preference for information and communications technology

- Relatively high number have had their principal work experience in micro-enterprises

Cluster 2 - 'Return on investment focused opportunity'

- Seeking return on investment

- Preference for logistics, transportation, etc.

- Disproportionately few females

- Slightly more medical and health sciences, and the least negatively disposed towards biotech

\section{Cluster 3 - 'General attributes opportunity'}

- Relatively high number from medium sized businesses

- Balanced importances (except capital intensity)

- Preference for fast food franchising

- Conservative with regard to technology

Cluster 4 - 'Capital intensive opportunity'

- Slightly more than average from commerce, law and management academic background; none from medical and health sciences

- Market growth and business sector are important; business consulting is preferred

- The only clusters where capital intensity was considered important, and capital intense was preferred over labour intense.

\section{Cluster 5 - 'Sector focused opportunity'}

- More females than males

- Disproportionate high number of individuals in the Arts Humanities

- Business sector is all that matters, preferring business consulting and then hospitality and tourism

- Prepared to go with innovative and unproven technology

\section{Discussion}

In line with calls for focused research that takes into consideration variation not only in the characteristics of venture founders but equally considers heterogeneity in venture opportunities (Shane \& Venkataraman, 2000), our research shows the advantages of clustering individuals on the basis of both business and demographic factors. To the best of our knowledge, the present study is one of the first to examine opportunity-based conceptualisations of entrepreneurship by suggesting that opportunities may be clustered on the basis of preferences.

Support was found for the hypothesis 1 in that there is a significant difference in the degree of importance attached to the business sector, capital intensity, technology maturity, market potential and return on investment potential when assessing an entrepreneurial business opportunity. Partial support was also found for hypothesis 2 in that there is a significant difference in the mean part worth utilities attributable to entrepreneurial opportunities in different business sectors, with differences detected in technology maturity. Additionally there is a significant positive correlation between the mean part worth utilities attributable to entrepreneurial opportunities and the expected market growth rate, and the return on investment potential. However there was insufficient evidence to support the hypothesis that there is a significant difference in the mean part worth utilities attributable to entrepreneurial opportunities that are capital versus labour intensive.

The results also support hypothesis 3 in that there is a significant difference in opportunity evaluation between demographic groups. Although there was weak support found for the hypothesis that respondents are heterogeneous in their evaluation of opportunities and may therefore be clustered on the basis of their preferences, five identifiable clusters were discernable. Even though in terms of the overall sample, only $34.05 \%$ of the variation of responses could be attributable to five identifiable clusters, support was found for the hypothesis that cluster membership is dependent on the gender, the academic background, and previous work experience of the individual. These findings are in line with the call for understanding the relationship between an entrepreneur's human capital profile and the opportunity identification process. This is an important theme that warrants additional research attention (Ucbasran, Westhead, \& Wright, 2008), particularly as understanding the motivating influence of potential financial reward on opportunity evaluation requires concomitant consideration of prior knowledge (Shepherd \& DeTienne, 2005). 
Entrepreneurs with superior human capital may draw upon their knowledge to reject less viable opportunities.

In terms of hypothesis 4 , where it was predicted that cluster membership is dependent on the family status, professional training, and the age of the individual, there was insufficient evidence to support this hypothesis. This result is surprising considering other researchers perceive opportunities as a mediator of the relationship between business owners' age and venture growth (Gielnik, Zacher \& Frese, 2010). Perhaps rather than viewing opportunities as single insights or attributing them to a particular individual, it is necessary to highlight the contextual and social influences that affect opportunity evaluation (Dimov, 2007b). Based on the tenets of the social cognitive theory, the likely interaction between personal factors and environmental influences needs to be accounted for, as it has been demonstrated that the interpretation of information is largely dependent on decision makers' expertise and their social standing. Based on the relatively low explanatory power of our empirical results, we agree that the inclusion of psychological and sociological constructs can enrich the study of venture capital investment allocation decisions (Dimov, Shepherd \& Sutcliffe, 2007).

Reflecting on the nomenclature used to identify the clusters we note that combining business and personal factors, based on cluster preferences, may result in somewhat curtailed opportunity sets. Recognising that the nature of differing opportunities can be calculated in terms of their utility values, as was demonstrated in the present study, it is proposed that most propositions about opportunities can be expressed more rigorously as propositions about how opportunity ideas can occur in qualitatively different contexts involving different types of preferences.

\section{Implications}

One of the strategies in promoting entrepreneurship is conducting research aimed at better understanding the different capacities and preferences of entrepreneurs, so that advisory services and financing can be more precisely targeted. Consequently understanding the opportunity evaluation process in terms of preferences and clusters may assist national policy makers who are trying to encourage more opportunity-focused entrepreneurial behaviour, particularly in an emerging market context. This is relevant as current definitions of entrepreneurs are too mechanistic to capture the complex reality of businesses in sectors, and a call for sector, industry or niche studies has been made to help orientate existing and prospective entrepreneurs (Rogerson, 2000). Often the small business market is so varied and diverse that it requires a classification tool which is not reliant on a one-dimensional view of the formality of the business (Finscope, 2006). There is a need for segmentation of different types of entrepreneurial opportunities, that go beyond targeting a single parameter to define an entrepreneurial opportunity.
Entrepreneurial activity in Africa is heavily skewed toward low-expectation entrepreneurial activity; according to the Global Entrepreneurship Monitor (GEM) report on highgrowth entrepreneurship (Autio, 2007). The relative prevalence of opportunity-based versus necessity-based entrepreneurial activity (i.e., entrepreneurs who say they are involved in an entrepreneurial effort to take advantage of opportunity versus because they have no better choices for work), provide useful insight into the quality of early-stage entrepreneurial activity (Autio, 2005). GEM research has consistently shown that the economic contribution of opportunity-driven entrepreneurs is higher than for necessity-driven entrepreneurs, who are often termed as survivalists since they not only face structural challenges, but expected returns are low and intermittent, with low expectations of growth and job creation, and where motivation is personal survival (Morris \& Pitt, 1995). This is in contrast to opportunity-driven entrepreneurs, who strive for independence, and have been found to differ systematically in terms of (1) expectations of job creation (2) projections for out-of-country exports (3) intention to replicate existing business activity yersus creating a new niche, and (4) participation in one of four business sectors (Hessels, van Gelderen \& Thurik, 2008; McMullen, Bagby \& Palich, 2008). Empirical evidence is mounting which demonstrates that there are more entrepreneurial opportunities in developing countries and that the higher number of entrepreneurial opportunities and demand for entrepreneurship in developing countries is indeed matched by higher rates of opportunity-driven entrepreneurs entering the market (Naude, 2010).

This study is not without limitations which include selfassessments of opportunity evaluation that are prone to cognitive and motivational bias. Moreover the results may have been affected by a reduction in statistical power through the use of some categorical variables. Clearly, more and more scholars today are underscoring the critical importance of opportunity to entrepreneurship (Ardichvili \& Cardozo, 2000; Gaglio \& Katz, 2001; Lumpkin, et al., 2004), and several gaps are currently missing in the literature which provides fertile ground for future research. For instance, future research could focus on opportunity evaluation attributes that tend to generate high-growth ventures, and on elements of human capital that are compatible with emerging market demographics.

A case is also made for focusing upon the opportunity rather than the firm or the entrepreneur as the unit of academic analysis, as this may bear some theoretical as well as empirical fruit to guide future research.

\section{References}

Alvarez, S.A. \& Busenitz, L.W. 2001. 'The entrepreneurship of resource-based theory, Journal of Management, 27: 755-775. 
Antoncic, B. \& Hisrich, R. D. 2001. 'Intrapreneurship: construct refinement and cross cultural validation', Journal of Business Venturing, 16: 495-527.

Ardichvili, A. \& Cardozo, R.N. 2000. A model of the entrepreneurial opportunity recognition process', Journal of Enterprising Culture, 8: 103-119.

Ardichvili, A., Cardoza, R., \& Ray, S. 2003. "A theory of entrepreneurial opportunity identification and development", Journal of Business Venturing, 18: 105-123.

Autio, E. 2005. Global Entrepreneurship Monitor. Report on high-expectancy entrepreneurship. [online] URL:http:/Www.gemconsortium.org.pdf.

Autio, E. 2007. Global Entrepreneurship Monitor. Report on high-expectancy entrepreneurship. [online] URL:http://www.gemconsortium.org.pdf.

Baron, R.A. 2004. 'The cognitive perspective: a valuable tool for answering entrepreneurships basic "why" questions', Journal of Business Venturing, 19: 221-239.

Baron, R.A. 2006. 'Opportunity recognition as pattern recognition: How entrepreneurs "connect the dots" to identify new business opportunities", Academy of Management Perspectives, 20: 104-119.

Bhave, M. 1994. 'A process model of entrepreneurial venture creation', Journal of Business Venturing, 9: 223242.

Bosma, N. \& Levie, J. 2009. Global Entrepreneurship Monitor global report. [online] URL:http://www.gemconsortium.org.pdf.

Busenitz, L.W. \& Lau, C.M. 1996. 'A cross cultural cognitive model of new venture creation', Entrepreneurship Theory and Practice, 20: 25-39.

Casson, M. 1982. The entrepreneur. Totowa, NJ: Barnes and Noble books.

Casson, M. 2005. 'The individual - opportunity nexus: A review of Seott Shane: A general theory of entrepreneurship', Small Business Economics, 24: 423 430.

Casson, M. \& Wadeson, N. 2007. 'The discovery of opportunities: extending the economic theory of the entrepreneur', Small Business Economics, 28: 285 - 300.

Cattell, R.B. 1966. 'The Scree Test for the number of factors', Multivariate Behavioural Research, 1: 245-276.

Companys, Y.E. \& McMullen, J.S. 2007. 'Strategic entrepreneurs at work: the nature, discovery, and exploitation of entrepreneurial opportunities', Small Business Economics, 28: 301 - 322.
Corbett, A.C. 2007. 'Learning symmetries and the discovery of entrepreneurial opportunities', Journal of. Business Venturing, 22: 97-118.

Davidsson, P. \& Honig, B. 2003. "The role of social and human capital among nascent entrepreneurs', Journal of Business Venturing, 18: 301-331.

Dickson, P.H., Solomon, G.T. \& Weaver, K.M. 2008. 'Entrepreneurial selection and success. does education matter?', Journal of Small Business and Enterprise Development, 15; 239-258.

Dimov, D. 2007a. 'Beyond the single-person, singleinsight attribution in understanding entrepreneurial opportunities', Entrepreneurship Theory and Practice, 11: $713-731$

Dimov, D. 2007b. 'From opportunity insight to opportunity intention: the importance of personsituation learning match', Entrepreneurship Theory and Practice, 10: 561-583.

Dimov, D. \& Milanov, H. 2010.'The interplay of need and opportunity in venture capital investment syndication', Journal of Business Venturing, 25: 331348.

Dimov, D., Shepherd, D. A. \& Sutcliffe, K.M. 2007. "Requisite expertise, firm reputation, and status in venture capital investment allocation decisions', Journal of Business Venturing, 22: 481-502.

Department of Trade \& Industry. 2006. Integrated strategy on the promotion of entrepreneurship and small enterprises. Pretoria: Department of Trade and Industry.

Dutta, D.K. \& Crossan, M.M. 2005. "The nature of entrepreneurial opportunities: understanding the process using the 4-I organizational learning framework', Entrepreneurship Theory and Practice, 3: 425-449.

Finscope. 2006. Small business survey report. Gauteng, Johannesburg: African Response.

Gaglio, C.M. \& Katz, J. 2001. 'The psychological basis of opportunity identification: entrepreneurial alertness', Journal of Small Business Economics, 16: 95-111.

Gartner, W.B. 2008. 'Variations in entrepreneurship", Small Business Economics, 31: 351-361.

Gielnik, M.M., Zacher, H. \& Frese, M. 2010.' Focus on opportunities as a mediator of the relationship between business owners" age and venture growth', Journal of Business Venturing, doi: 10.1016/j.jbusvent.2010.05.002.

Goedhuys, M. \& Sleuwaegen, L. 2010. 'High-growth entrepreneurial firms in Africa: a quantile regression approach', Small Business Economics, 34: 31-51. 
Goosen, C.J., De Coning, T.J. \& Smit, E.V d M. 2002. 'Corporate entrepreneurship and financial performance: the role of management', South African Business Management, 33:21-27.

Gries, T. \& Naude, W. 2010.' Entrepreneurship and structural economic transformation', Small Business Economics, 34: 14-29.

Haynie, I.M., Shepherd, D.A. \& McMullen, J.S. 2009. "An opportunity for me? The role of resources in opportunity evaluation decisions', Journal of Management Studies, 46 : 337-361.

Hessels, J., Van Gelderen, M. \& Thurik, R. 2008. 'Entrepreneurial aspirations, motivations, and their drivers', Small Business Economics, 31: 323-339.

Hills, G. \& Singh, R.P. 2004. 'Opportunity Recognition. In Gartner, W.B., Shaver, K.G., Carter, N.M. \& Reynolds, P.D (Eds.). Handbook of Entrepreneurial Dynamics. California: Sage Publications.

Hills, G., Schrader, R. \& Lumpkin, T. 1999. 'Opportunity recognition as a creative process', Frontiers of Entrepreneurship Research, 12: 216-227.

Hintze, J. 2001. NCSS and PASS. Number Cruncher Statistical Systems. Kaysville, Utah: NCSS.

Hirschsohn, P. 2008. Regulating the animal spirits of entrepreneurs? Skills development in South African small and medium enterprises", International Small Business Joumal, 26: 181-206.

Hisrich, R.D. 2000. 'Entrepreneurial dimensions: the relationship of individual, venture, and environmental factors to success', Entrepreneurship Theory and Practice, 24: $79-90$.

Jantunen, A.K., Puumalainen, S., Saarenketo, S. \& Kylaheiko, K. 2005. 'Entrepreneurial orientation, dynamic capabilities and international performance', Journal of International Entrepreneurship, 3: 223-243.

Jeffrey, G., York, S. \&Venkataraman, S. 2010. 'The entrepreneur-environment nexus: Uncertainty, innovation, and allocation', Journal of Business Venturing, 25: $449-$ 463.

Kaish, S. \& Gilad, B. 1991. 'Characteristics of opportunity search for entrepreneurs versus executives: sources, interests, and general alertness', Journal of Business Venturing, 6: 45-61.

Kirzner, I.M. 1973. Entrepreneurship and competition. Chicago: University of Chicago Press.

Kirzner, I.M. 1979. Perception, opportunity, and profit. Chicago: Beard Books.
Knight, F.H. 1942. 'Profit and entrepreneurial functions', Journal of Economic History, 2: 126-131.

Krueger, N.F. 2000. 'The cognitive infrastructure of opportunity emergence', Entrepreneurship Theory and Practice, 24, 5-23.

Lee, J.H. \& Venkataraman, S. 2006. "Aspirations, market offerings, and the pursuit of entrepreneurial opportunities', Journal of Business Venturing, 21: $107-123$.

Lu, J. \& Tao, Z. 2008. 'Determinants of entrepreneurial activities in China', Journal of Business Venturing, 25; 261273.

Luiz, J. 2006. Managing business in Africa, practical management theory for an emerging market. South Africa: Oxford University Press.

Lumpkin, G. T, Hills, G. E. \& Shrader, R.C. 2004. Opportunity recognition. In Welsch, H. (Ed.). Entrepreneurship: The Road Ahead. London: Routledge

McMullen, S.J., Bagby, D.R. \& Palich, L.E. 2008. 'Economic freedom and the motivation to engage in entrepreneurial action', Entrepreneurship Theory and Practice, 7: 875-895.

McMullen, J.S., Plummer, L.A. \& Acs, Z.A. 2007. "What is entrepreneurial opportunity?" Small Business Economics, 28: $273-283$.

Morris, M. H. \& Pitt, L.F. 1995. 'Informal sector activity as entrepreneurship: insights from a South African township', Journal of Small Business Management, 4: 78-86.

Muzychenko, O. 2008. 'Cross-cultural entrepreneurial competence in identifying international business opportunities", European Management Journal, 26: 366377.

Naude, W. 2010. 'Entrepreneurship, developing countries and development economics: new approaches and insights", Small Business Economics, 34: 1-12.

Qzgen, E. \& Baron, R.A. 2007. 'Social sources of information in opportunity recognition: effects of mentors, industry networks, and professional forums", Journal of Business Venturing, 22: 174-192.

Plummer, L.A., Haynie, J.M. \& Godesiabois, J. 2007. 'An essay on the origins of entrepreneurial opportunity', Small Business Economics, 28:363 - 379.

Pretorius, M., Millard, S.M \& Kruger, M.E. 2005. 'Creativity, innovation and implementation: management experience, venture size, the cycle stage, race and gender as moderators", South African Journal of Business Management, 36: 55-68. 
Rogerson, C.M. 2000. 'Emerging from Apartheid's shadow; South Africa's informal economy', Journal of International Affairs, 53: 673-695.

Saayman, M, Saayman, A. \& Slabbert, E. 2011. 'Who spends and who does not: Clustering visitors at a national arts festival," South African Journal of Business Management, 42: 9-15.

Samuelsson, M. \& Davidsson, P. 2009. 'Does venture opportunity variation matter? Investigating systematic process differences between innovative and imitative new ventures', Small Business Economics, 33:229- 255.

Sawtooth Software, Inc. 2002. Conjoint Value Analysis (CVA) System. Sawtooth Software Market Research Tools (SMRT), Orem, Utah: Sawtooth Software.

Schumpeter, J.A. 1971. The fundamental phenomenon of economic development. In Kilbey, P. (ed.). Entrepreneurship and Economic Development. New York: Free Press.

Seda. 2007, Review of trends on entrepreneurship and the contribution of small enterprises to the economy of South Africa, 2000-2006. Johannesburg: African Enterprise Development Agency.

Shane, S. 2000. A general theory of Entrepreneurship. The individual-opportunity nexus. Entrepreneurship education series. Northampton, MA: Edward Elgar.

Shane, S. \& Venkataraman, S. 2000. 'The promise of entrepreneurship as a field of research", Academy of Management Review, 25: 217-235.

Shepherd, D.A. \& De Tienne, D.R. 2005. 'Prior knowledge, potential financial reward, and opportunity identification', Entrepreneurship Theory and Practice, 6:91-112.

Shepherd, D.A. \& Zacharakis, A. 1997. Conjoint analysis: a window of opportunity for entrepreneurship. In Katz, J. (ed.). Advances in entrepreneurship, firm emergence and growth. (Vol. 3, pp. 203-248). Greenwich, CT: JAI Press.

Singh, R.P. 2000. Entrepreneurial opportunity recognition through social networks. New York: Garland.

Thukral, I., Von Ehr, J., Walsh, S., Groen, A.J., Van Der Sijde P. \& Adham, K.A. 2008. 'Entrepreneurship, emerging technologies, emerging markets', International Small Business Journal, 26: 101-116.

Timmons, J. A. 2002. New Venture Creation. $6^{\text {th }}$ edition. Burr Ridge, Ill.: Irwin.

Timmons, J.A. 1994. New Venture Creation. $4^{\text {th }}$ edition. Burr Ridge, Ill.; Irwin.

Ucbasaran, D., Westhead, P. \& Wright, M. 2008. Opportunity identification and pursuit: does an entrepreneur's human capital matter?' Small Business Economics, 30: $153-173$.

Ucbasaran, D., Westhead, P. \& Wright, M. 2001. 'The focus of entrepreneurial research: contextual and process issues," Entrepreneurship Theory and Practice, 25:34-45.

Urban, B. 2010. 'Cognitions and motivations for new venture creation decisions: linking expert scripts to selfefficacy, a South African study, International Journal of Human Resource Management, 21: 1512-1530.

Van Zyl, H.J.C. \& Mathur-Helm, B. 2007. 'Exploring a conceptual model, based on the combined effects of entrepreneurial leadership, market orientation and relationship marketing orientation on South Africa's small tourism business performance', South Africa Journal of Business Management, 38:17-24.

Venkataraman, S. 1997. The distinctive domain of entrepreneurship research', Advances in Entrepreneurship, Firm Emergence and Growth, 3: 119-138.

Walsh, J.P. 1988. 'Selectivity and selective perception; an investigation of manager's belief structures and information processing,' Academy of Management Journal, 31: 873-896.

Wennberg, K. \& Holmquist, C. 2008. 'Problemistic search and international entrepreneurship, ${ }^{2}$ European Management Joumal, 26: 441-454.

Westhead, P. Ucbasaran, D. \& Wright, M. 2009. Information search and opportunity identification: the importance of prior business ownership experience," International Small Business Journal, 27: 659-680. 